\title{
Correction to: Genetic variation of Mycoplasma hyopneumoniae from Brazilian field samples
}

Viviane Sisdelli Assao ${ }^{1}$, Thalita Moreira Scatamburlo", Elaine Nery Araujo1, Marcus Rebouças Santos', Carlos Eduardo Real Pereira², Roberto Maurício Carvalho Guedes², Gustavo Costa Bressan?', Juliana Lopes Rangel Fietto', Yung-Fu Chang ${ }^{3}$, Maria Aparecida Scatamburlo Moreira ${ }^{1}$ and Abelardo Silva-Júnior ${ }^{1 *}$

\section{Correction to: BMC Microbiol}

\section{https://doi.org/10.1186/s12866-019-1603-7}

Following publication of the original article [1], we have been notified that two of the author names were incomplete or incorrect.

Originally published author names:

- Thalita M Scatamburlo

- Maria Aparecida Scatambulo Moreira

Correct author names:

- Thalita Moreira Scatamburlo

- Maria Aparecida Scatamburlo Moreira

The original article has been corrected.

\section{Author details}

${ }^{1}$ Federal University of Viçosa, Viçosa, Minas Gerais, Brazil. ${ }^{2}$ Federal University

of Minas Gerais, Belo Horizonte, Minas Gerais, Brazil. ${ }^{3}$ Cornell University

College of Veterinary Medicine, Ithaca, USA.

Published online: 20 November 2019

\section{Reference}

1. Assao, et al. Genetic variation of Mycoplasma hyopneumoniae from

Brazilian field samples. BMC Microbiol. 2019;19:234. https://doi.org/10.1186/ s12866-019-1603-7.

* Correspondence: abelardo.junior@ufv.br

${ }^{1}$ Federal University of Viçosa, Viçosa, Minas Gerais, Brazil

Full list of author information is available at the end of the article

(c) The Author(s). 2019 Open Access This article is distributed under the terms of the Creative Commons Attribution 4.0 International License (http://creativecommons.org/licenses/by/4.0/), which permits unrestricted use, distribution, and reproduction in any medium, provided you give appropriate credit to the original author(s) and the source, provide a link to the Creative Commons license, and indicate if changes were made. The Creative Commons Public Domain Dedication waiver (http://creativecommons.org/publicdomain/zero/1.0/) applies to the data made available in this article, unless otherwise stated. 